\title{
THE IMPACT OF LUXURY HOUSING ON NEIGHBORHOOD HOUSING PRICES: AN APPLICATION OF THE SPATIAL DIFFERENCE-IN-DIFFERENCES METHOD
}

\author{
Chih-Min LIANG ${ }^{1}$, Chun-Chang LEE2, ${ }^{2}$, You-Hsin LIN ${ }^{2}$, Zheng YU², Wen-Chih YEH ${ }^{2, * *}$ \\ ${ }^{1}$ Department of Public Finance and Tax Administration, National Taipei University of Business, Taipei, Taiwan \\ ${ }^{2}$ Department of Real Estate Management, National Pingtung University, Pingtung, Taiwan
}

Received 09 September 2019; accepted 07 June 2020

\begin{abstract}
This study investigated the spatial spillover effects of luxury housing during and after construction, in regards to increases in housing prices in neighboring areas as well as the spatial dependence of neighboring housing. This study focused on already completed luxury housing in Taipei, Taiwan. First, the nearest-neighbor matching approach of propensity score matching was used to overcome the problem of data heterogeneity. The difference-in-differences (DD) method and spatial econometrics were used for analysis. The empirical results indicated that the spatial error model had the best goodness of fit. This indicated that housing prices increased by $13.0 \%$ during construction of luxury housing nearby. This indicated that housing prices increased by $5.8 \%$ after the construction of luxury housing nearby. The empirical results showed that the ongoing and completed construction of luxury housing had spillover effects on housing prices. The effect of ongoing construction of luxury housing was particularly large in scope, indicating its role as a predictor of psychological reaction in the market.
\end{abstract}

Keywords: luxury housing, propensity score matching, difference-in-differences, spatial dependence, spatial lag model, spatial error model.

\section{Introduction}

With the improvement of living standards in Taiwan, housing now constitutes the highest expenditure with respect to the basic necessities of life. In addition to considering affordability, transportation convenience, and location when choosing housing, people have recently started pursuing high-standard, high-quality, high-profile, and high-priced housing.

In recent years, citizens of Taiwan have paid more attention to quality of life. This has led to the development of a new type of housing, referred to in the market as luxury housing, derived from existing types of housing such as condominiums, studios, multi-story houses, and high-rise suites. Lin and Jou (2005) described typical luxury housing as housing with rare spatial resources such as beautiful landscapes and good locations, and characterized by a high total price, a large living space, good facilities, and high prestige. According to the 15th provision of the "Property Price and Present Value Appraisal Criteria" as established by the Taipei City Revenue Service, buildings that are made from reinforced concrete or belong to a higher construction class are used for residential purposes. Properties with a total value of over NT $\$ 80$ million, and a total registered area of ownership over 80 ping (1 ping is equal to 3.306 square meter) or a per apartment price of over NT\$1 million per ping (excluding parking spaces), are defined as high-level housing or luxury housing. According to Wang (2008), luxury housing is a small market segment targeting upper class consumers; Wang suggested that such housing is showy by nature, and its target consumers are relatively homogeneous, which provides a cluster effect. Lin (2004) maintained that luxury housing has shaped a particular lifestyle for upper class society, and that it is not only local landmark, but also an indicator of wealth and ostentation.

Past studies on luxury housing have discussed historical development, purchase decision-making, integrated marketing, and positioning design of luxury housing (e.g. Lin \& Jou, 2005; Ho, 2011; Wu, 2008; Chen, 2011). However, there is a lack of research regarding the effect of luxury housing on neighborhood housing prices.

\footnotetext{
${ }^{*}$ Corresponding author. E-mail: lcc@mail.nptu.edu.tw

${ }^{*}$ Department of Real Estate Management, HungKuo Delin University of Technology, New Taipei, Taiwan

Copyright $\odot 2020$ The Author(s). Published by Vilnius Gediminas Technical University
}

This is an Open Access article distributed under the terms of the Creative Commons Attribution License (https://creativecommons.org/licenses/by/4.0/), which permits unrestricted use, distribution, and reproduction in any medium, provided the original author and source are credited. 
Ooi and Le (2013) suggested that newly constructed buildings can have external or spillover effects on neighborhood housing, and these effects are positive in the case of luxury housing. According to Hsu (2005), individual housing needs can benefit from the "basking in reflected glory" (BIRG) phenomenon where the characteristics of the surrounding community help improve self-image; this involves location-, brand-, and quality-recognition, all of which promote the neighborhood effect of luxury housing. High-priced products such as luxury housing are likely to be surrounded by other expensive houses, whereas lowcost houses are surrounded by other low-cost houses. This mutual effect of housing prices gives rise to the concept of spatial dependence, referred to as spatial autocorrelation. Under the BIRG and neighborhood effects, the high prices of luxury housing have spillover effects, raising neighborhood housing prices.

This study examined whether luxury housing affects housing prices in neighboring areas. The research field included 12 administrative districts of Taipei City. The difference-in-differences (DD) method was used to analyze the effect of luxury housing on housing prices in neighboring areas during (indicated by a building permit) and after (indicated by an occupancy permit) construction. Housing prices were evaluated using spatial econometric analysis. It should be noted that the use of the DD method must account for the problem of heterogeneity between two sets of samples, which is often neglected by researchers. Rosenbaum and Rubin (1985) proposed the propensity score matching method (PSM) which overcomes the problem of bias by increasing the homogeneity between the sample data in an experimental group and a control group. This study aimed (1) to investigate how, and to what degree, luxury housing affects housing prices in neighboring areas during and after its construction, and (2) to examine the differences in the effects of luxury housing on housing prices in neighboring areas during and after construction. This study used the DD method to analyze the influence of luxury housing on housing prices in neighboring areas within an experimental group and a control group. The traditional ordinary least squares (OLS) regression model and the spatial lag and spatial error models of spatial econometrics were used for evaluation.

\section{Literature review}

In reality, housing prices can produce spatial cluster and spatial spillover effects. Areas with high-cost (or low-cost) housing can aggregate to form one area, as can areas with high (or low) consumption. Lin and Jou (2005) and Hsu (2005) suggested that the inhabitants of luxury housing come to a consensus in the pursuit of quality of life, which allows a certain level of pricing to be maintained within the community. Lin (2004) maintained that luxury housing has shaped a particular lifestyle for upper class society, and that it is not only a local landmark, but also an indicator of wealth and ostentation. Consumers often view luxury housing as a symbol of wealth, thereby improving the effect and assessment of residential quality for neighboring houses in the proximity of luxury housing. Chou (2012) suggested that in order to improve self-esteem, individuals associate themselves with successful people. Likewise, the perception of the value of luxury housing as a product signifying privilege, luxury, honor, and status gives residents of neighboring houses a stronger sense of identity and distinction. According to Wu (2010), highquality housing is a symbol of status, and communities with luxury housing are characterized by cluster and ostentation. Boen et al. (2002) also maintained that successful groups evoke feelings of adoration and empathy in individuals and increase their self-esteem, motivating them to buy similar products to increase association.

Luxury housing normally has rare spatial resources such as beautiful landscapes and a good location. Its designed streets and clean environment make it appearanceoriented. Heil and Helsen (2001) suggested that better location is associated with higher housing prices. Such areas may also be unique due to their products. Bourassa et al. (2004) indicated that buildings with unique appearance can increase real estate prices in neighboring areas by $37 \%$ and that improved housing with unique appearances can increase real estate prices in neighboring areas by $27 \%$, whereas real estate prices surrounded by lower-quality environments can decrease prices by $51 \%$. François et al. (2002) found that in Quebec City, Canada, beautiful streetscapes could increase housing prices by $4.4 \%$. Bourassa et al. (2005) indicated that housing prices could increase if there were beautiful waterscapes or landscapes near the housing. Ooi and Le (2013) suggested that newly constructed buildings can have external effects on neighboring housing. Luxury housing has positive external and spillover effects on housing in neighboring areas. The external effects produced by luxury housing make the neighboring environment more attractive, which increases housing prices in neighboring areas. Such external benefits are referred to as neighborhood effects. Chen (2008) pointed out that although luxury housing is not a public facility, it has an effect similar to the benefits of a park. The external effects of parks provide advantages for neighboring housing, producing spillover effects and increasing housing prices in neighboring areas. Using the Hedonic Pricing Method regression model, Tseng (2014) evaluated the capitalization effects associated with the neighborhood effects of luxury housing; the results indicated that the pricing of housing decreased by $0.4 \%$ each time its distance from luxury housing was increased by 100 meters, with an estimated impact range of approximately 2,000 meters.

This study investigated the effect of luxury housing on housing prices in neighboring areas during and after its construction. The DD method was used for empirical analysis, as it was the most suitable method. With regard to past studies on DD, Tang and Yao (2012) evaluated the effect of the Olympics on real estate prices in Beijing. Beijing, where the 2008 Summer Olympic Games were held, 
was included in the experimental group, while other cities that have not hosted the Olympics were included in the control group. The results showed that factors relating to the Olympics resulted in a progressive increase and subsequent decrease of neighboring real estate prices, whereas in cities outside the influence of the Olympics, real estate prices changed in line with the economic cycle. Lee et al. (2018) examined the difference in housing prices within and outside the areas neighboring luxury housing. The experimental group included an area within 500 meters of luxury housing and the control group included areas outside this range. The results showed that luxury housing increased housing prices in neighboring areas. Kavetsos (2012) used the DD method to analyze changes in the prices of housing neighboring the Olympics sports venues in London before and after the event; the empirical results showed that housing prices in those areas increased by $2.1-3.3 \%$, reaching a significant level.

With regard to the effects of facilities such as public transport, schools, and parks on housing prices in neighboring areas, the issue of spatial dependence caused by interdependence of housing prices is often not taken into account. Can (1990) used the Moran test and the Lagrange multiplier (LM) to test spatial autocorrelation of housing prices; the results indicated a clear presence of spatial dependence in the error terms of housing price and better explanatory power of the spatial autoregression model with regard to housing prices as compared with the OLS regression model. Many studies, such as Can and Megbolugbe (1997), Pace and Gilley (1997), Basu and Thibodeau (1998), Dubin et al. (1999), and Case et al. (2004), compared different spatial econometric models and the OLS model and found that spatial econometric analysis greatly improved the accuracy of housing price evaluations by solving the error caused by spatial autocorrelation. The findings of Bourassa et al. (2010) showed that the accuracy of housing price evaluation could be improved by combining spatial econometric analysis and the sub-market as defined by the housing characteristic variable. Baltagi et al. (2015) analyzed the mutual effect of housing prices in neighboring areas based on data from 2000-2007, and used 353 districts in England as the criteria. The results showed that the spatial lag factor had a significant positive effect and could make neighboring houses rise or fall in price. This study integrated the DD method and a spatial econometric model to analyze the effect of spatial dependence.

\section{Empirical model}

This study first used the OLS method to estimate the benchmark DD model, followed by identifying the possible spatial dependence in housing prices, and then examining the spillover effects of the construction or completion of luxury housing on housing prices nearby through the use of the spatial error model (SEM) and the spatial lag model (SLM) used in spatial econometrics. Property attributes were arranged and analyzed using a geographic information system (GIS) and the spatial econometric analysis software Geoda.

This study primarily used the difference in difference (DD) approach to examine the causal effects between events. Even though this approach can eliminate the effects of unobservable factors on housing prices, the housing prices in this study were obtained through observations in lieu of experimental methods. Moreover, differences are present in characteristic variables, and housing prices might not be influenced by the disclosure of information. In order to address this problem in sample heterogeneity, this study followed the recommendations of Imbens (2015) and used the propensity score matching method (PSM) proposed by Rosenbaum and Rubin (1985). In PSM, matching is used to screen samples in the control group, thereby overcoming the problem of selection bias caused by heterogeneity in large sample sizes.

(1) Benchmark difference-in-difference method

This study analyzed spillover effects of luxury housing during and after its construction. Luxury housing that was being constructed was indicated by a construction license and luxury housing that had been already constructed was indicated by a usage license. With regard to determination of the experimental and control groups, Ellen et al. (2001) investigated housing in New York by using 500 meter radius to distinguish between the research and control areas. Dempsey and Plantinga (2013) applied the DD method and used a 500 meter radius to distinguish between the experimental and control areas. Liang (2009) compared spillover effects of urban redevelopment projects and used a 500-meter radius to distinguish between the research and control areas. Lee et al. (2018) analyzed housing prices within the neighborhood range of luxury housing; the experimental group included houses within 500 meters form luxury housing and the control group included houses outside this range. In this study, houses located within 500 meters from luxury housing were included in the experimental group and those located outside this range were included in the control group. The benchmark empirical DD model is shown in equation (1):

$$
\begin{aligned}
& \ln P_{i t}=\beta_{1}+\beta_{2} \text { AREA }_{i t}+\beta_{3} A G E_{i t}+\beta_{4} \text { AGES }_{i t}+ \\
& \beta_{5} \text { FLOOR }_{i t}+\beta_{6} \text { ROOM }_{i t}+\beta_{7} \text { LIVROOM }_{i t}+ \\
& \beta_{8} \text { BATH }_{i t}+\beta_{9} \text { TYPE }_{i t}+\beta_{10} \text { MRT }_{i t}+\beta_{11} \text { HISC }_{i t}+ \\
& \beta_{12} \text { JUNI }_{i t}+\beta_{13} \text { PRIM }_{i t}+\sum_{j=14 \sim 24} \beta_{j} R E G_{j i t}+ \\
& \beta_{25} \text { TREAT }_{i}+\beta_{26} \text { TIME }_{t}+\delta\left(T R E A T_{i} \times \text { TIME }_{t}\right)+\varepsilon_{i t} .
\end{aligned}
$$

The dependent variable in this study was the logarithm of total housing price $(\operatorname{In} P)$ and the independent variables included building transfer area (AREA), house age (AGE), square of house age (AGES), residence floor (FLOOR), number of rooms (ROOM), number of living rooms (LIVROOM), number of bathrooms (BATH), housing type (TYPE), distance to the nearest MRT station (MRT), distance to nearest senior high school (HISC), distance to nearest junior high school (JUNI), distance to nearest pri- 
mary school (PRIM) and administrative district dummies (REG). The DD variables included TREAT, TIME, and TIME $\times$ TREAT. $\varepsilon_{i t}$ is error term, $\beta^{\prime} s$ is the coefficient of each independent variable, and $\delta$ is the DD coefficient, which reflects the treatment effect of the construction or completion of luxury housing on housing prices nearby.

(2) Spatial difference-in-difference method

Dubin (1998) stated that the housing market requires a method that would accurately estimate housing prices. The OLS model does not consider spatial dependence of housing prices in neighboring areas. The spatial lag model differs from the OLS model in that it adds a neighborhood matrix of housing prices as an extra explanatory variable in order to analyze the effect of neighboring areas. Failure to consider this in the OLS model can lead to errors due to the omission of important variables. Case et al. (2004) compared spatial econometric analysis and the OLS model and found that spatial econometric analysis solves bias caused by the issue of spatial autocorrelation in evaluation of housing prices. This study applied the DD method and developed a spatial lag model and spatial error model. Explanatory variables in the spatial lag model included the dependent variable of spatial lag. The concept of spatial lag is basically similar to the lag effect of preceding time on current time in the time series model. The statistical significance of the spatial lag coefficient of the dependent variable $\rho$ was tested. The $\rho \neq 0$ indicated spatial relations in neighboring areas in the autoregressive model. The spatial lag model is shown in the equation (2):

$$
Y=\rho W Y+X \beta+\varepsilon,
$$

where: $Y$ is a vector formed by $\operatorname{In} P ; X$ is the matrix formed by explanatory variables in the benchmark model (1); $\beta$ is a corresponding coefficient vector; $\varepsilon$ is an i.i.d. error vector; $W$ is a row-standardized spatial Queen contiguity matrix; and $\rho$ is the spatial lag coefficient. ${ }^{1} \rho \neq 0$ indicates the spatial dependence of housing prices, the spatial autocorrelation of neighborhood housing prices, and, thus, a neighborhood effect. In order to examine the differences between housing prices in relation to space, this study used the SEM, as shown in equations (3) and (4):

$$
\begin{aligned}
& Y=X \beta+\varepsilon ; \\
& \varepsilon=\lambda W \varepsilon+u .
\end{aligned}
$$

SEM conducts autocorrelation of an error term in the benchmark model. The error term $\varepsilon$ in equation (3) may produce spatial dependence due to the presence of latent

\footnotetext{
1 Gibbons et al. (2015) mentioned that contiguity and inverse distance weight matrix can be used to solve identification problems in spatial econometric models. Stata 15 also has built-in features for these two weight matrices. However, in the inverse distance matrix, a threshold distance (or bandwidth) beyond which there is no direct spatial influence between spatial units must be selected beforehand. In order to avoid arbitrariness caused by threshold selection, this study employed the queen contiguity weight matrix to check whether spatial units had a neighboring border (including vertex).
}

variables and is, therefore, no longer i.i.d. Correction in equation (4) uses spatial aggregation so that the final error term $u$ is i.i.d. $\lambda$ is the spatial autoregressive coefficient. $\lambda \neq 0$ indicates the spatial dependence of the error term; housing prices may be affected by neighborhood housing prices, which causes spatial autocorrelation.

\section{(3) Variable selection}

The explanatory variables in this study included basic property attributes, administrative district properties, and DD properties. Basic property attributes included housing area (AREA), house age (AGE), square of house age (AGES), residence floor (FLOOR), number of rooms (ROOM), number of living rooms (LIVROOM), number of bathrooms (BATH), and housing type (TYPE). Taipei City has 12 administrative districts. We used Wanhua District as our basis of reference and set the other 11 districts as dummy variables. DD properties included time of construction/usage license acquisition by luxury housing (TIME), neighboring and non-neighboring areas of luxury housing (TREAT), and the interaction variable of time of construction/usage license acquisition and neighboring and non-neighboring areas of luxury housing. Basic property attributes and administrative district properties were set according to the Hedonic Pricing Theory and were regarded as control variables in this study. The definitions and explanation of the variables are provided in Table 1.

The dependent variable in this study was the logarithm of total housing purchase price $(\operatorname{In} P)$. Past studies conducted analysis using transaction item price or total price as the dependent variable. The estimation of transaction unit price allows us to avoid errors in price evaluation results caused by different size of real estate (McLean et al., 2013; Tsoodle et al., 2006), while the estimation of total price allows us to effectively examine comprehensive data and the overall price of housing (Song \& Knapp, 2003; Karl \& Gareth, 2005). Dubé et al. (2014) suggested that logarithmized data related to dependent variables is closer to normal distribution in comparison to raw data; moreover, the conditional distribution of strictly positive variable often are heteroskedastic or skewed, taking the log can mitigate both problem (Anglin \& Gencay, 1996; Gibbons et al., 2013). The log-linear functional form does not only reduce data heterogeneity. In the case of non-linear functional forms, the law of diminishing marginal returns is also said to be demonstrated if the slope estimate has a negative value after the logarithmic transformation of a dependent variable. For example, So et al. (1997) mentioned that the log-linear functional form is rational and is the optimum option for evaluating non-linear models. Many studies used the logarithms of residential prices in their estimations (e.g. Dubé et al., 2013; Zietz et al., 2008; Cordera et al., 2019). As the evaluation results based on the logarithm of total housing transaction price corresponded to those expected in this study, the logarithm of total housing transaction price was selected as the dependent variable for analysis. 
Table 1. Variable explanation

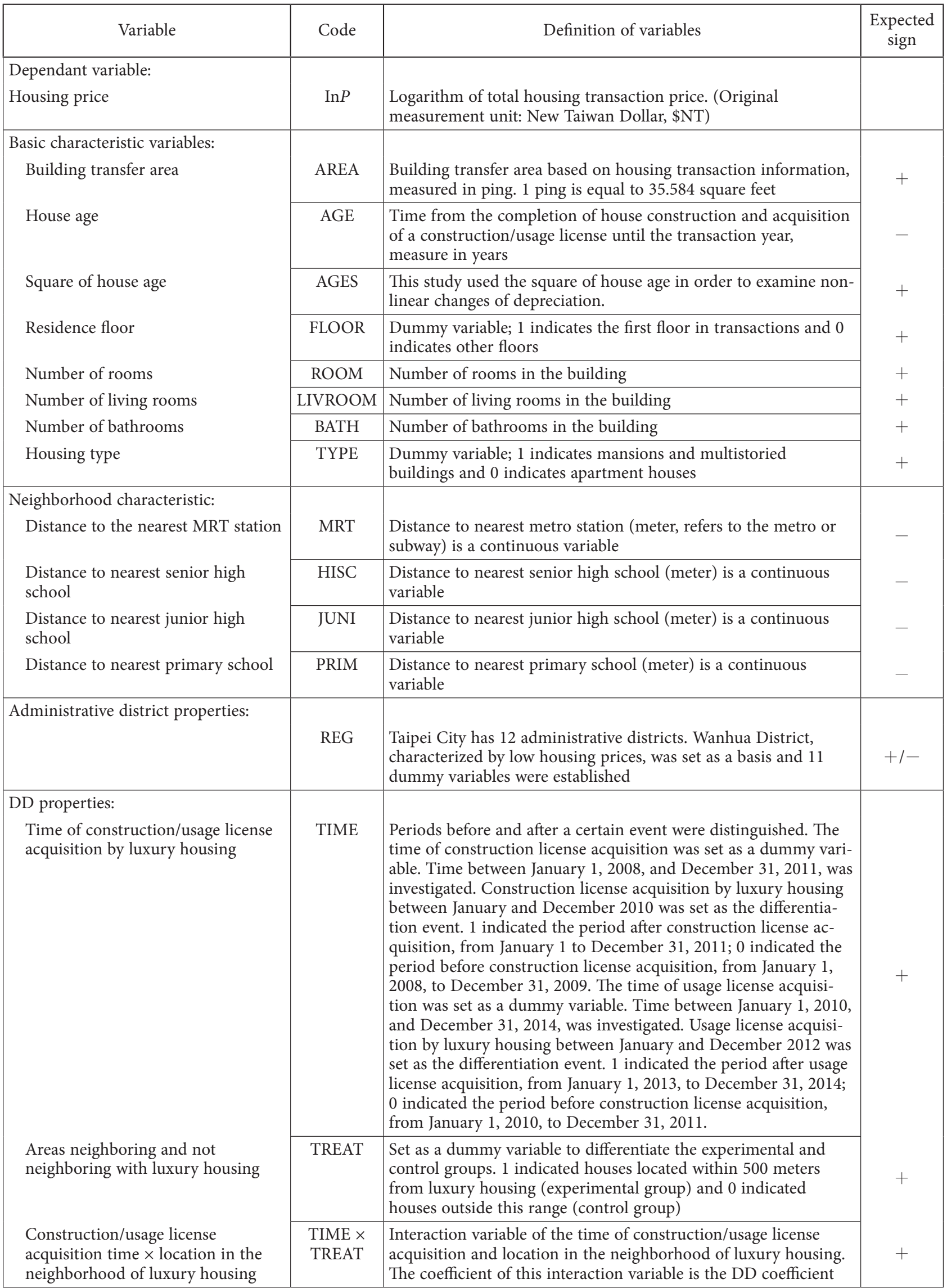


The acquisition of a construction or usage license for luxury housing can affect housing prices in neighboring areas. Ooi and Le (2013) suggested that newly constructed multistoried buildings have positive or negative external and spillover effects on neighboring housing, whereas luxury housing has positive external effects on neighboring housing. Luxury housing can increase real estate prices in neighboring areas during and after its construction. Due to clean and well-planned streets and unique appearance of luxury housing that is being or has been constructed, the neighborhood attributes becomes more attractive, having a positive effect on neighboring areas. Chen (2008) suggested that the amenity benefit of urban parks is a characteristic property of housing prices that is beneficial for surrounding houses, producing spillover effects on and increasing housing market prices, which results in the growth of housing prices in neighboring areas. This study expected that there would be a significant difference in the effect of luxury housing on housing prices before and after acquisition of a construction or usage license.

Buildings located within 500 meters from luxury housing were defined as being located in the neighboring areas of luxury housing. Houses within the luxury housing influence range were included in the experimental group and indicated as 1 , while houses outside this range were included in the control group and indicated as 0 . The effect of luxury housing on housing prices within and outside 500-meter range was investigated. Lee et al. (2018) examined the difference in housing prices within and outside the luxury housing range, determining areas within 500 meters from luxury housing as the experimental group and areas outside the 500-meter range as the control group. François et al. (2002) found that in Quebec City, Canada, beautiful streetscape can increase housing prices by $4.4 \%$. This study predicted that there would be a significant difference between average housing prices in neighboring areas of luxury housing and other areas.

The DD coefficient in this study was the coefficient of the interaction variable of construction/usage license acquisition time and location in the neighborhood of luxury housing (i.e. cross-multiplication of the two dummy variables). Luxury housing has a positive effect on housing prices in neighboring areas as it esthetically enhances the neighborhood attributes through its unique style and beautiful appearance. Tang and Yao (2012) investigated the effect of the Olympics on housing prices in Beijing; the results indicated that the Olympics increased housing prices in Beijing that were particularly high in the periods close to the opening of the Olympics. This study expected that housing prices would be positively affected by interaction between time of construction/usage license acquisition and location in the neighboring areas of luxury housing.

\section{Data sources and descriptive statistics of the sample}

\subsection{Development of luxury housing in Taipei City}

According to Lin and Jou (2005), high-level housing referred to as luxury housing in the market is housing with such rare spatial resources as beautiful landscape and good location, in addition to having a high total price, large living space, good facilities, and high ratings. This housing type can direct the development of urban housing standards and marketing methods and has market indicators and symbolic implications. The standards examined and approved by the Real Estate Assessment Committee of Taipei City include eight indicators of high-level housing, which are detached buildings, luxurious appearance, good district, beautiful landscape, small number of residents on each floor, parking space, strict safety requirements, and thorough management. The following conditions were revised and expanded based on the opinions of different social circles and specialists: (1) The total price of each apartment is NT\$80 million and more. (2) Price per ping is NT $\$ 1$ million and more and the area of each apartment is 80 ping and more. (3) At least $70 \%$ of apartments in each house meet the requirements described above. Definition of luxury housing by the Central Bank of Taiwan mainly refers to the basis of assessment provided in the Mansion Tax of Taipei City. The assessment range includes real estate for which the total price is NT\$80 million or more in Taipei City and New Taipei City and real estate priced (total price) in the range of NT\$50 million or more in other areas of Taiwan.

The official definition of a luxury housing was promulgated between 2011 and 2012, and during the period between 2008 and 2014 that this study covered, no amendments were made to the official definition. This research adopted the DD method, in which the duration of a luxury housing project was regarded as an event. This study aimed to understand the effects of the construction or the completion of luxury housing projects on nearby housing prices. Therefore, the changes in luxury housing prices in the market were not the focus of this study.

Taipei City is Taiwan's political and economic center with active commercial life. Therefore, compared to other areas, its housing transactions are characterized by less stability and its luxury housing market is more developed. Taipei City has the largest number of luxury houses in Taiwan. Having consumers from the top of the social pyramid, Taipei City has the highest luxury housing prices in Taiwan. The sky-high prices of real estate have brought about the preference toward luxury housing, larger living areas, apartments occupying the entire floor, emphasis on rare services and facilities, strict security, and open space and landscape (Lin \& Jou, 2005). Expensive first-rate housing determines standards and marketing of urban housing overall. Therefore, luxury housing is often seen as having indicative and symbolic implication in the real estate market. Currently, most luxury housing circulates in Taipei City market and is divided into suburban and downtown housing. Three types of housing can be distinguished based on the year of its construction, the district it is located in, and housing type. The first type mainly includes unique suburban luxury housing located in Yangmingshan. The second type includes the first-generation 
downtown luxury housing constructed after the 1970s and mainly located on Dunhua Street and Ren'ai Street. The third type includes the second-generation downtown luxury housing constructed in the late 1990s and mainly located in the Xinyi Planning District (Zang, 2001). Luxury housing with water landscape located in Dazhi and Dawan areas can also be distinguished. Due to the instability in the real estate market activities as caused by high-price housing, on July 1, 2012, the Taipei Revenue Service introduced a tax on high-level housing prices (the Mansion Tax) to suppress house price speculations.

The luxury housing cases investigated in this study mainly include downtown houses in Zhongzheng District, Songshan District, and Da'an District. All of them are characterized by good location, convenient transport, good neighborhood attributes, improved life conditions, unique building design, and value and potential.

\subsection{Source of data}

The housing transaction data in this study was obtained from the reports on Taiwan real estate transactions between January 1, 2008, and December 31, 2011 as published by the real estate company Giga House; and the net price data from the period between January 2013 and December 2014 as provided by the Ministry of the Interior. In total, the sample included six-year data on housing transactions. This study extracted transaction data related to apartment houses and multistoried buildings. Other data included housing transaction prices, floor area, house age, and number of floors, thus, providing all necessary data on property attributes. This study examined real estate in 12 administrative districts of Taipei City. However, the collected data was not entirely related to housing transactions. Therefore, this study excluded data not related to housing, for instance, transactions related to land, parking, kitchens, offices, buildings within buildings, and shops and incomplete data. Large differences between properties in different housing transactions resulted in outliers in housing transaction data due to assessment error. This study excluded $5 \%$ of the sample with the lowest and highest housing prices in each administrative district in order to prevent abnormal data from affecting statistical results. The final sample for empirical analysis included 17,787 items. After propensity score matching, the numbers of obtained data points related to the initiation and completion of construction events were 5,124 and 7,647, respectively.

Furthermore, data was collected from the real estate transaction price inquiry website of the Ministry of the Interior, websites of public-works corporations, and other housing information websites. ${ }^{2}$ According to the provi-

\footnotetext{
2 The real estate transaction price inquiry website of the Ministry of the Interior, accessed on 1 June 2016, URL: http://lvr. land.moi.gov.tw/homePage.action. HOUSEtube, accessed on 1 June 2016, URL: http://deluxe.housetube.tw., accessed on 1 June 2016, URL: http://www.park.com.tw/index.php.
}

sion 15 of the Directions Governing Property Transaction Standard Prices and the Evaluation of Housing Net Prices in Taipei City, luxury housing is characterized by detached buildings, luxurious appearance, good district, beautiful landscape, small number of residents on each floor, strict safety requirements, parking space, and thorough management. Reinforced concrete or higher-class material is used in the construction of such houses, which are used for residential purposes. Buildings with a total price if over NT $\$ 80$ million per apartment, registered ownership of over 80 ping, and NT $\$ 1$ million per ping (not including parking space) were defined as luxury housing.

In this study, five cases of luxury housing that obtained a construction license within 2010 and five cases that obtained a usage license within 2012 were examined as research cases. All the cases were in located in Zhonzheng District, Songshan District, or Dảan District. This study collected housing transaction data for the period between January 1, 2008, and December 31, 2014. The DD method requires the data to be broken down into data generated before and after the event. Therefore, this period was selected to ensure integrity and consistency of data before and after the event.

The house price index in Taiwan from 2001 to 2014 is shown in Figure 1 (Lin, 2012). The figure shows that housing prices increased significantly due to the implementation of quantitative easing by central banks in response to the 2007 subprime mortgage crisis and 2008 global financial crisis. We can see that from 2008 to 2014, the growth rate of housing prices was over $85 \%$. Housing prices in Taipei City also increased from 2008 to 2014. The reason behind this is that during this period, the lack of flexibility in the supply side had resulted in marginal differences in the existing housing supply compared to that in the past (Housing Statistics Data, Construction and Planning Agency, Ministry of the Interior. Link: https://www.cpami. gov.tw/index.php?option $=$ com_categorytable\&view $=$ cate gorytable\&categoryid=138\&Itemid=129). On the supply side, however, in response to the unconventional monetary policy of quantitative easing, the Central Bank of the Republic of China drastically reduced interest rate levels to close to zero. Under such conditions in which mortgage costs are extremely low, housing demands had surged dramatically, which resulted in surging housing prices.

After PSM treatment, the experimental and control groups were almost homogenous, indicating that the DD approach can eliminate the common variations and trends in both groups. Therefore, external changes around Taipei City have the same effects on the experimental and control groups, i.e. a common trend is present. In other words, external changes do not influence the impacts of luxury housing on the difference in housing prices between the two groups.

Figures 2 and 3 show the luxury housing cases in Taipei City and their housing transactions during and after construction, respectively. 


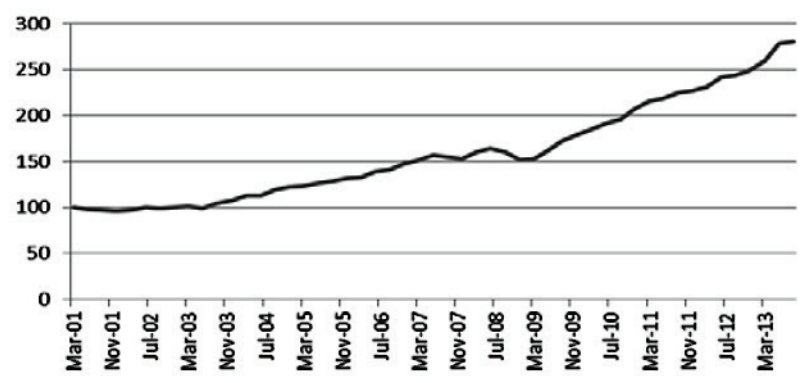

Figure 1. Sinyi House Price Index: Taiwan (source: Sinyi Research Center For Real Estate)

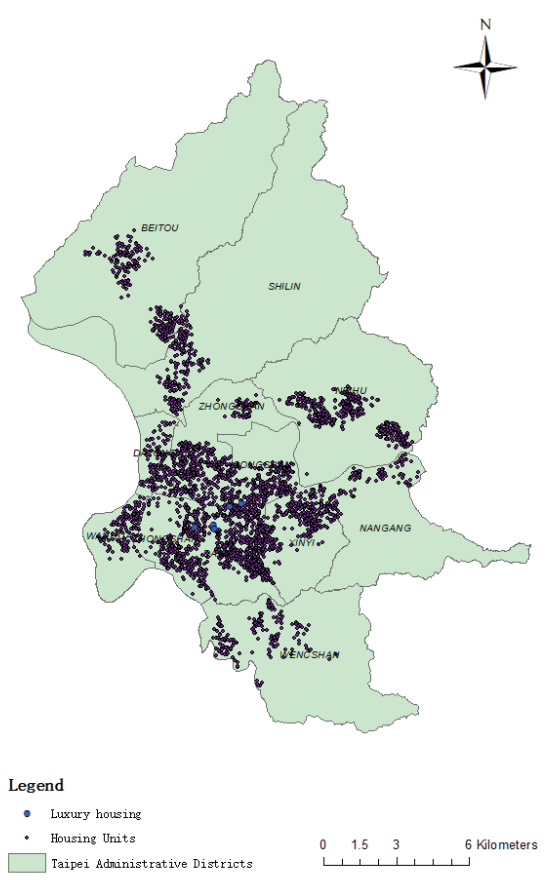

Figure 2. Luxury housing cases in Taipei City and housing transactions during construction

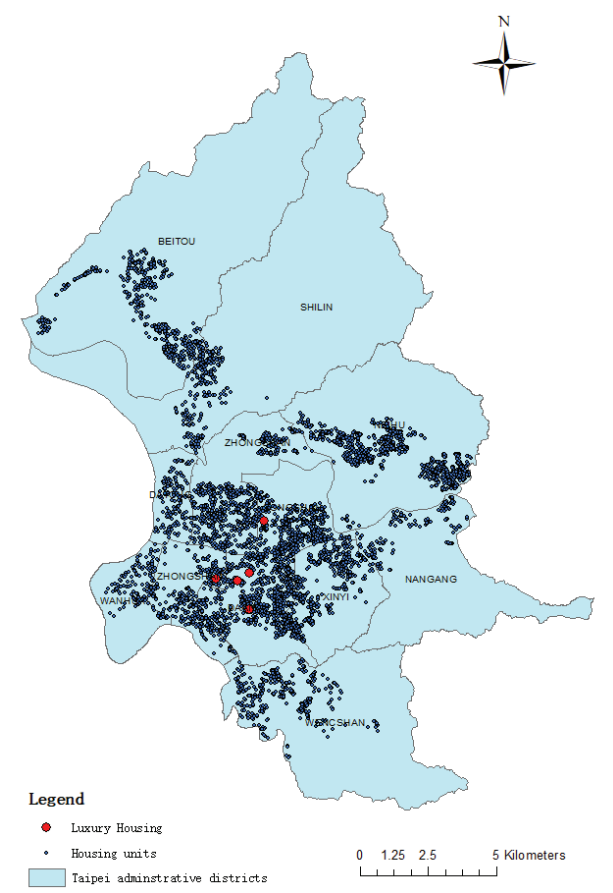

Figure 3. Luxury housing cases in Taipei City and housing transactions after construction

\subsection{Data processing}

At first, the housing characteristics observed in the experimental and control groups were not completely the same. This led to the problem of selection bias, which cannot be eliminated completely through the difference in difference method. The matching method proposed by Rubin (1979) includes the analysis of a counterfactual framework analysis $^{3}$, where the samples with similar housing characteristics in the experimental and control groups were matched, thus significantly reducing the differences in characteristic variables between the two groups of samples. The matching method offers two advantages over conventional regression analysis: (i) it introduces the benefits of randomized experiments into observational studies; and (ii) it reduces the non-observable sensitivity of a model (Stuart \& Rubin, 2008).

In the propensity score matching method (PSM) proposed by Rosenbaum and Rubin (1985), during the matching process, each housing characteristic variable was converted into a probability, so as to predict if a house was located within the influence range of luxury housing and, thereby, overcome the problem of a reduced sample size caused by imposing multiple matching conditions for variables at the same time. The advantage of the PSM is that the experimental and control groups are or almost are balanced in terms of matching conditions (Kuan \& Lee, 2008). There are various methods for calculating matched data. According to Morgan and Harding (2006), different PSM matching methods generate different estimates. Walls et al. (2017) suggested that the k-nearest neighbor matching approach can be used to control various non-observable variables in certain applications, as well as for eliminating the differences between these variables. Therefore, we adopted the k-nearest neighbor matching approach proposed by Walls et al. (2017), in which $\mathrm{k}$ is set as 1 . Then, a housing sample located beyond the influence range of luxury housing was matched with a sample located within the range, where a matched sample was determined as having the least difference in propensity scores. In this study, the variables in the PSM included area (AREA), house age $(A G E)$, number of rooms (ROOM), number of living rooms (LIVROOM) and bathrooms (BATH), housing type (TYPE), residence floor (FLOOR), distance to the nearest MRT station $(M R T)$, distance to the nearest senior high school (HISC), distance to the nearest junior high school (JUNI) and distance to the nearest primary school (PRIM).

After the matching process was completed, t-tests and chi-squared $\left(\chi^{2}\right)$ tests were then performed to evaluate the quality of the matches, validate if the matches were able to balance the distribution of variables in the two

\footnotetext{
3 According to Kuan and Lee (2008), in a counterfactual framework, there are two types of responses in each state - the responses generated after experimental treatment, and the responses generated without experimental treatment. Hence, a counterfactual framework is also known as a potential outcome model.
} 
groups of samples, and check if self-selection bias was effectively reduced. As shown in Table 2, before matching, there were 352 samples in the experimental group and 6,940 samples in the control group, with significant differences being observed in terms of the number of rooms, number of living rooms, housing type, residence floor, distance to the nearest MRT station, distance to the nearest senior high school, and distance to the nearest junior high school. After matching, there were 352 samples in the experimental group and 4,772 samples in the control group, and in this case, significant differences in the variables were not observed, with the exception of the number of rooms and housing type. As shown in Table 3, before matching, there were 542 samples in the experimental group and 9,953 samples in the control group, with significant differences being observed in terms of the number of rooms, number of living rooms, housing type, residence floor, distance to the nearest MRT station, distance to the nearest senior high school, and distance to the nearest junior high school. After matching, there were 541 samples in the experimental group and 7,106 samples in the control group, and in this case, significant differences in the variables were not observed, with the exception of housing type.

Table 2. Differences in mean values between the experimental group and the control group during construction

\begin{tabular}{|c|c|c|c|c|c|c|}
\hline \multirow[b]{2}{*}{ Variable } & \multicolumn{3}{|c|}{ Before matching } & \multicolumn{3}{|c|}{ After matching } \\
\hline & $\begin{array}{l}\text { Treated group } \\
\quad(\mathrm{N}=352)\end{array}$ & $\begin{array}{l}\text { Control group } \\
(\mathrm{N}=6,940)\end{array}$ & $\mathrm{t}$-value & $\begin{array}{l}\text { Treated group } \\
(\mathrm{N}=352)\end{array}$ & $\begin{array}{c}\text { Control group } \\
(\mathrm{N}=4,772)\end{array}$ & t-value \\
\hline AREA & 30.501 & 31.614 & -1.280 & 30.501 & 30.265 & 0.180 \\
\hline AGE & 20.903 & 20.091 & 1.280 & 20.903 & 21.322 & -0.460 \\
\hline ROOM & 2.293 & 2.492 & $-3.940^{* * *}$ & 2.293 & 2.452 & $-2.060^{\star *}$ \\
\hline LIVROOM & 1.591 & 1.773 & $-7.010^{* * *}$ & 1.591 & 1.625 & -0.880 \\
\hline BATH & 1.446 & 1.451 & -0.150 & 1.446 & 1.477 & -0.680 \\
\hline MRT & 290.630 & 554.350 & $-11.160^{\star * *}$ & 290.630 & 275.740 & 1.320 \\
\hline HISC & 402.650 & 676.610 & $-12.160^{* * *}$ & 402.650 & 389.060 & 0.910 \\
\hline JUNI & 475.090 & 529.020 & $-3.400^{* * *}$ & 475.090 & 472.080 & 0.180 \\
\hline PRIM & 390.430 & 377.690 & 1.160 & 390.430 & 387.770 & 0.220 \\
\hline Type & Frequency & Frequency & $\chi^{2}$ & Frequency & Frequency & $\chi^{2}$ \\
\hline $\begin{array}{l}\text { MULTISTORIED } \\
\text { BUILDINGS } \\
\end{array}$ & 274 & 4,674 & $16.91^{\star * *}$ & 274 & 3,431 & $5.78^{\star \star}$ \\
\hline APARTMENT HOUSES & 78 & 2,266 & & 78 & 1,341 & \\
\hline FLOOR & Frequency & Frequency & $\chi^{2}$ & Frequency & Frequency & $\chi^{2}$ \\
\hline FLOOR1 & 10 & 392 & $5.07^{\star *}$ & 10 & 200 & 1.52 \\
\hline NONFLOOR1 & 342 & 6,548 & & 342 & 4,572 & \\
\hline
\end{tabular}

Note: ${ }^{* *},{ }^{* *}$, and ${ }^{*}$ indicate that the coefficient reaches the $1 \%, 5 \%$, and $10 \%$ level of significance, respectively; significantly different from 0.

Table 3. Differences in mean values between the experimental group and the control group after construction

\begin{tabular}{|l|c|c|c|c|c|c|}
\hline \multirow{2}{*}{ Variable } & \multicolumn{3}{|c|}{ Before matching } & \multicolumn{3}{c|}{ After matching } \\
\cline { 2 - 7 } & $\begin{array}{c}\text { Treated group } \\
(\mathrm{N}=542)\end{array}$ & $\begin{array}{c}\text { Control group } \\
(\mathrm{N}=9,953)\end{array}$ & t-value & $\begin{array}{c}\text { Treated group } \\
(\mathrm{N}=541)\end{array}$ & $\begin{array}{c}\text { Control group } \\
(\mathrm{N}=7,106)\end{array}$ & \multicolumn{1}{c|}{$\mathrm{t}$-value } \\
\hline AREA & 34.824 & 33.692 & $1.730^{*}$ & 34.810 & 35.007 & -0.220 \\
\hline AGE & 26.329 & 24.157 & $4.300^{* * *}$ & 26.286 & 26.618 & -0.520 \\
\hline ROOM & 2.602 & 2.668 & $-1.690^{*}$ & 2.604 & 2.649 & -0.740 \\
\hline LIVROOM & 1.840 & 1.799 & $1.990^{* *}$ & 1.839 & 1.847 & -0.240 \\
\hline BATH & 1.630 & 1.611 & 0.740 & 1.629 & 1.647 & -0.450 \\
\hline MRT & 302.180 & 628.310 & $-15.890^{* * *}$ & 302.340 & 302.040 & 0.030 \\
\hline HISC & 507.980 & 725.530 & $-11.090^{* * *}$ & 507.920 & 514.520 & -0.340 \\
\hline JUNI & 415.650 & 551.230 & $-9.770^{* * *}$ & 416.190 & 408.900 & 0.580 \\
\hline PRIM & 437.370 & 390.470 & $4.890^{* * *}$ & 437.040 & 427.340 & 0.900 \\
\hline Type & Frequency & Frequency & $\chi^{2}$ & Frequency & Frequency & $\chi^{2}$ \\
\hline $\begin{array}{l}\text { MULTISTORIED } \\
\text { BUILDINGS }\end{array}$ & 456 & 6,067 & $117.37^{* * *}$ & 455 & 4,880 & $56.73^{* * *}$ \\
\hline APARTMENT HOUSES & 86 & 3,886 & & 86 & 2,226 & \\
\hline FLOOR & Frequency & Frequency & $\chi^{2}$ & Frequency & Frequency & $\chi^{2}$ \\
\hline FLOOR1 & 32 & 789 & $2.92^{*}$ & 32 & 478 & 0.53 \\
\hline NONFLOOR1 & 510 & 9,164 & & 509 & 6,628 & \\
\hline
\end{tabular}

Note: ${ }^{* *},{ }^{* *}$, and ${ }^{*}$ indicate that the coefficient reaches the $1 \%, 5 \%$, and $10 \%$ level of significance, respectively; significantly different from 0. 


\subsection{Descriptive statistics of the data}

The acquisition of a construction license was set as the event (Table 4). The average total price of housing (PRICE) was NT\$1,439.89, with the standard deviation of NT\$1,113.18. The average housing area (AREA) was 30.93 ping, with the standard deviation of 16.42 ping. The average house age $(A G E)$ was 20.13 years, with the standard deviation of 11.82 years. The mean value of the residence floor (FLOOR) was 0.041 , indicating that $4.1 \%$ of house residents lived on the 1 st floor and $95.9 \%$ lived on other floors. The mean value of the housing type (TYPE) was 0.723 , indicating that multistoried buildings and apartment houses accounted for $72.3 \%$ and $27.7 \%$ of the sample, respectively. The average number of rooms $(R O O M)$ was 2.40 , with the standard deviation of 0.95 . The average number of living rooms (LIVROOM) was 1.70 , with the standard deviation of 0.49 . The average number of bathrooms $(B A T H)$ was 1.44, with the standard deviation of 0.58 . The average distance to the nearest MRT station (MRT) was 357 meter, with the standard deviation of 200.04 meter. The average distance to nearest senior high school (HISC) was 495.42 meters, with the standard deviation of 243.69 meters. The average distance to nearest junior high school (JUNI) was 486.83 meters, with the standard deviation of 232.19 meters. The average distance to nearest primary school (PRIM) was 373.09 meters, with the standard deviation of 173.44 meters.

The acquisition of a usage license was set as the event (Table 5). The average total price of housing (PRICE) was NT $\$ 1,892.83$, with the standard deviation of NT $\$ 1,153.54$. The average housing area (AREA) was 33.73 ping, with

Table 4. Descriptive statistics: During construction - Construction license acquisition

\begin{tabular}{|l|c|c|c|c|}
\hline \multicolumn{1}{|c|}{ Variable } & Mean & Standard deviation & Min. & Max. \\
\hline PRICE (ten thousand NT\$) & $1,439.89$ & $1,113.18$ & 44 & 23,100 \\
AREA (ping) & 30.93 & 16.42 & 2.14 & 174.43 \\
AGE (year) & 20.13 & 11.82 & 0.10 & 53.80 \\
ROOM & 2.40 & 0.95 & 1 & 5 \\
LIVROOM & 1.70 & 0.49 & 1 & 5 \\
BATH & 1.44 & 0.58 & 1 & 5 \\
TMRT & 357.00 & 200.04 & 3.40 & 1397.44 \\
HISC & 495.42 & 243.69 & 13.11 & 1561.37 \\
JUNI & 486.83 & 232.19 & 17.56 & 1613.65 \\
PRIM & 373.09 & 173.44 & 16.42 & \\
\hline & Frequency & Percent & Cumulative percent & \\
\hline TYPE & & & & \\
MULTISTORIED BUILDINGS & 3,705 & 72.31 & 72.31 & \\
APARTMENT HOUSES & 1,419 & 27.69 & & \\
\hline FLOOR & & & & \\
FLOOR1 & 210 & 4.10 & 4.00 & \\
NONFLOOR1 & 4,914 & 95.90 & 100.00 & \\
\hline
\end{tabular}

Table 5. Descriptive statistics: After construction - Usage license acquisition

\begin{tabular}{|l|c|c|c|c|}
\hline \multicolumn{1}{|c|}{ Variable } & Mean & Standard deviation & Min. & Max. \\
\hline PRICE (ten thousand NT\$) & $1,892.83$ & $1,153.54$ & 217 & 33300 \\
AREA (ping) & 33.73 & 15.06 & 7.85 & 312 \\
AGE (year) & 24.61 & 11.51 & 0.1 & 55 \\
ROOM & 2.62 & 0.90 & 1 & 9 \\
LIVROOM & 1.80 & 0.47 & 1 & 8 \\
BATH & 1.60 & 0.59 & 1 & 8 \\
MRT & 415.77 & 229.40 & 2.46 & 1572.23 \\
HISC & 607.72 & 395.44 & 14.36 & 3617.10 \\
JUNI & 469.33 & 239.28 & 15.79 & 1561.37 \\
PRIM & 388.40 & 184.45 & 19.158 & 1334.04 \\
\hline & Frequency & Percent & Cumulative percent & \\
\hline TYPE & & & & \\
MULTISTORIED BUILDINGS & 5,335 & 69.77 & 69.77 & \\
APARTMENT HOUSES & 2,312 & 30.23 & & \\
\hline FLOOR & & & & \\
FLOOR1 & 510 & 6.67 & 6.67 & \\
NONFLOOR1 & 7,137 & 93.33 & 100.00 & \\
\hline
\end{tabular}


the standard deviation of 15.06 ping. The average house age (AREA) was 24.61 years, with the standard deviation of 11.51 years. The mean value of the residence floor $(F L O O R)$ was 0.068 , indicating that $6.8 \%$ of house residents lived on the 1st floor and $93.2 \%$ lived on other floors. The mean value of the housing type (TYPE) was 0.698 , indicating that multistoried buildings and apartment houses accounted for $69.8 \%$ and $30.2 \%$ of the sample, respectively. The average number of rooms ( $R O O M)$ was 2.62 , with the standard deviation of 0.90 . The average number of living rooms (LIVROOM) was 1.80 , with the standard deviation of 0.47 . The average number of bathrooms $(B A T H)$ was 1.60 , with the standard deviation of 0.59 . The average distance to the nearest MRT station (MRT) was 415.77 meter, with the standard deviation of 229.40 meter. The average distance to nearest senior high school (HISC) was 607.72 meters, with the standard deviation of 395.44 meters. The average distance to nearest junior high school (JUNI) was 469.33 meters, with the standard deviation of 239.28 meters. The average distance to nearest primary school (PRIM) was 388.40 meters, with the standard deviation of 184.45 meters.

\section{Empirical results}

This study investigated the effect of luxury housing on housing prices in neighboring areas during (indicated by a construction license) and after (indicated by a usage license) its construction. The spatial concepts were integrated into the regression model in order to solve the issues of spatial heterogeneity and spatial autocorrelation in the traditional OLS model. As shown in Table 6, Moran's I reached the $1 \%$ level of significance both during and after construction, indicating the presence of positive autocorrelation and spatial clustering in housing prices in areas neighboring with luxury housing. Housing prices in administrative districts showed positive autocorrelation. The spatial dependence test was further used to determine which spatial model had the best explanatory power. Both LM-lag and LM-error reached the $1 \%$ level of significance. Both Robust LM-lag and Robust LM-error reached the 1\% level of significance. Thus, the residuals differed in terms of heterogeneity. The results of the spatial lag model and spatial error model were further compared.
(1) During construction

Table 7 shows the results of evaluating the period after construction using the three models (OLS, SLM, SEM). The Breusch-Pagan test was used to determine heteroscedasticity of residuals. Its values in the three models were $1483.72,1436.74$, and 1523.74 , reaching the $1 \%$ level of significance. The value in the spatial error model was the highest, indicating heteroscedasticity of its residuals. $R^{2}$ was equal to $0.797,0.807$, and 0.813 ; the spatial error model showed the highest explanatory power. Smaller AIC and SC values indicate better goodness of fit. AIC was equal to $1948.61,1708.89$, and 1642.35 and SC was equal to $2125.23,1892.06$, and 1818.97. The larger log likelihood values indicate better goodness of fit. The log likelihood values of the models were $-947.30,-826.45$, and -794.17 , indicating that the spatial lag model and spatial error model had better goodness of fit. The results described above showed that the spatial error model was better than the traditional OLS regression model and spatial lag model. The evaluation results show that the spatial error model had the best goodness of fit. The results of the spatial error model are discussed further.

With regard to property attributes, the building transfer area coefficient was 0.022 , reaching the $1 \%$ level of significance, which indicated that the housing price increased by $2.2 \%$ with each additional ping of the building transfer area. The house age coefficient was -0.013 , reaching the $1 \%$ level of significance. The coefficient of the square of house age was 0.001 , reaching the $1 \%$ level of significance, which indicated prices of older housing were lower and such decrease in prices was decreased. The residence floor coefficient was 0.129 , reaching the $1 \%$ level of significance, which indicated that the prices of housing located on the first floor were $12.9 \%$ higher than that on other floors. The coefficient of the number of rooms was 0.086 , reaching the $1 \%$ level of significance, which indicated that the housing price increased by $8.6 \%$ with each additional room. The coefficient of the number of living rooms was 0.173 , reaching the $1 \%$ level of significance, which indicated that the housing price increased by $17.3 \%$ with each additional living room. The coefficient of the number of bathrooms was 0.083 , reaching the $1 \%$ level of significance, which indicated that the housing price increased by $8.3 \%$ with each additional bathroom. The housing type coefficient

Table 6. Spatial dependence during and after construction of luxury housing

\begin{tabular}{|l|c|c|c|c|}
\hline \multirow{2}{*}{ Test } & \multicolumn{2}{|c|}{ During construction } & \multicolumn{2}{c|}{ After construction } \\
\cline { 2 - 5 } & MI/DF & Z(I) value & MI/DF & Z(I) value \\
\hline Moran's I & $0.1381^{* * *}$ & 21.626 & $0.2078^{* * *}$ & 34.996 \\
\hline LM-lag & 1 & $289.411^{* * *}$ & 1 & $848.676^{* * *}$ \\
\hline LM-error & 1 & $57.076^{* * *}$ & 1 & $95.030^{* * *}$ \\
\hline Robust LM-lag & 1 & $435.721^{* * *}$ & 1 & $1183.005^{* * *}$ \\
\hline Robust LM-error & 1 & $203.386^{* * *}$ & 1 & $429.358^{* * *}$ \\
\hline
\end{tabular}

Note: MI/DF indicate Moran's I and degrees of freedom. ${ }^{* *},{ }^{* *}$, and ${ }^{*}$ indicate that the coefficient reaches the $1 \%, 5 \%$, and $10 \%$ level of significance, respectively; significantly different from 0 . 
Table 7. Empirical results for the period during construction and after construction of luxury housing

\begin{tabular}{|c|c|c|c|c|c|c|}
\hline & \multicolumn{3}{|c|}{ During construction $(\mathrm{N}=5124)$} & \multicolumn{3}{|c|}{ After construction $(\mathrm{N}=7647)$} \\
\hline & OLS & $\begin{array}{l}\text { Spatial lag } \\
\text { model }\end{array}$ & $\begin{array}{c}\text { Spatial error } \\
\text { model }\end{array}$ & OLS & $\begin{array}{l}\text { Spatial lag } \\
\text { model }\end{array}$ & $\begin{array}{c}\text { Spatial error } \\
\text { model }\end{array}$ \\
\hline Independent variable & $\begin{array}{l}\text { coefficient } \\
\text { (S.E.) }\end{array}$ & $\begin{array}{l}\text { coefficient } \\
\text { (S.E.) }\end{array}$ & $\begin{array}{l}\text { coefficient } \\
\text { (S.E.) }\end{array}$ & $\begin{array}{l}\text { coefficient } \\
\text { (S.E.) }\end{array}$ & $\begin{array}{l}\text { coefficient } \\
\text { (S.E.) }\end{array}$ & $\begin{array}{l}\text { coefficient } \\
\text { (S.E.) }\end{array}$ \\
\hline Intercept & $\begin{array}{c}5.260^{* * *} \\
(0.035)\end{array}$ & $\begin{array}{c}3.914^{* * *} \\
(0.091)\end{array}$ & $\begin{array}{c}5.267^{* * *} \\
(0.047)\end{array}$ & $\begin{array}{c}6.010^{* * *} \\
(0.029)\end{array}$ & $\begin{array}{c}3.958^{* * *} \\
(0.082)\end{array}$ & $\begin{array}{c}6.055^{* * *} \\
(0.042)\end{array}$ \\
\hline AREA & $\begin{array}{c}0.023^{* * *} \\
(0.001)\end{array}$ & $\begin{array}{c}0.022^{* * *} \\
(0.001)\end{array}$ & $\begin{array}{c}0.022^{* * *} \\
(0.001)\end{array}$ & $\begin{array}{c}0.018^{* * *} \\
(0.001)\end{array}$ & $\begin{array}{c}0.017^{\star * *} \\
(0.001)\end{array}$ & $\begin{array}{c}0.017^{* * *} \\
(0.001)\end{array}$ \\
\hline AGE & $\begin{array}{l}-0.013^{* * *} \\
(0.001)\end{array}$ & $\begin{array}{c}-0.013^{* * *} \\
(0.001)\end{array}$ & $\begin{array}{c}-0.013^{* * *} \\
(0.001)\end{array}$ & $\begin{array}{c}-0.004^{* * *} \\
(0.001)\end{array}$ & $\begin{array}{c}-0.004^{* * *} \\
(0.001)\end{array}$ & $\begin{array}{c}-0.004^{* * *} \\
(0.001)\end{array}$ \\
\hline AGES & $\begin{array}{c}0.001^{\star * *} \\
(0.001)\end{array}$ & $\begin{array}{c}0.001^{* * *} \\
(0.001)\end{array}$ & $\begin{array}{c}0.001^{\star * *} \\
(0.001)\end{array}$ & $\begin{array}{c}0.001^{* * *} \\
(0.001)\end{array}$ & $\begin{array}{c}0.001^{* * *} \\
(0.001)\end{array}$ & $\begin{array}{c}0.001^{* * *} \\
(0.001)\end{array}$ \\
\hline FLOOR & $\begin{array}{c}0.124^{\star * *} \\
(0.021)\end{array}$ & $\begin{array}{c}0.126^{* * *} \\
(0.020)\end{array}$ & $\begin{array}{c}0.129^{* * *} \\
(0.020)\end{array}$ & $\begin{array}{c}0.221^{* * *} \\
(0.013)\end{array}$ & $\begin{array}{c}0.219^{* * *} \\
(0.012)\end{array}$ & $\begin{array}{c}0.221^{* * *} \\
(0.012)\end{array}$ \\
\hline ROOM & $\begin{array}{c}0.085^{\star * *} \\
(0.007)\end{array}$ & $\begin{array}{c}0.085^{* * *} \\
(0.007)\end{array}$ & $\begin{array}{c}0.086^{\star * *} \\
(0.007)\end{array}$ & $\begin{array}{c}0.082^{* * *} \\
(0.005)\end{array}$ & $\begin{array}{c}0.078^{* * *} \\
(0.005)\end{array}$ & $\begin{array}{c}0.081^{* * *} \\
(0.005)\end{array}$ \\
\hline LIVROOM & $\begin{array}{c}0.167^{* * *} \\
(0.012)\end{array}$ & $\begin{array}{c}0.166^{* * *} \\
(0.011)\end{array}$ & $\begin{array}{c}0.173^{\star * *} \\
(0.011)\end{array}$ & $\begin{array}{c}0.097^{* * *} \\
(0.008)\end{array}$ & $\begin{array}{c}0.088^{* * *} \\
(0.008)\end{array}$ & $\begin{array}{c}0.092^{* * *} \\
(0.008)\end{array}$ \\
\hline BATH & $\begin{array}{c}0.087^{* * *} \\
(0.010)\end{array}$ & $\begin{array}{c}0.085^{\star * *} \\
(0.010)\end{array}$ & $\begin{array}{c}0.083^{* * *} \\
(0.010)\end{array}$ & $\begin{array}{l}0.018^{* *} \\
(0.007)\end{array}$ & $\begin{array}{c}0.017^{\star * *} \\
(0.007)\end{array}$ & $\begin{array}{c}0.019^{* * *} \\
(0.007)\end{array}$ \\
\hline TYPE & $\begin{array}{c}0.068^{\star * *} \\
(0.012)\end{array}$ & $\begin{array}{c}0.073^{* * *} \\
(0.012)\end{array}$ & $\begin{array}{c}0.069^{* * *} \\
(0.012)\end{array}$ & $\begin{array}{c}0.272^{* * *} \\
(0.008)\end{array}$ & $\begin{array}{c}0.255^{\star * *} \\
(0.008)\end{array}$ & $\begin{array}{c}0.289^{* * *} \\
(0.008)\end{array}$ \\
\hline Location fixed effects & yes & yes & yes & yes & yes & yes \\
\hline TIME & $\begin{array}{c}0.427^{* * *} \\
(0.009)\end{array}$ & $\begin{array}{c}0.427^{\star * *} \\
(0.009)\end{array}$ & $\begin{array}{c}0.430^{* * *} \\
(0.009)\end{array}$ & $\begin{array}{c}0.218^{* * *} \\
(0.008)\end{array}$ & $\begin{array}{c}0.211^{* * *} \\
(0.007)\end{array}$ & $\begin{array}{c}0.228^{* * *} \\
(0.007)\end{array}$ \\
\hline TREAT & $\begin{array}{c}0.021 \\
(0.024)\end{array}$ & $\begin{array}{c}0.012 \\
(0.023)\end{array}$ & $\begin{array}{c}0.003 \\
(0.029)\end{array}$ & $\begin{array}{l}0.050^{* *} \\
(0.021)\end{array}$ & $\begin{array}{c}0.014 \\
(0.020)\end{array}$ & $\begin{array}{c}0.027 \\
(0.026)\end{array}$ \\
\hline $\mathrm{DD}$ & $\begin{array}{c}0.146^{* * *} \\
(0.033)\end{array}$ & $\begin{array}{c}0.132^{* * *} \\
(0.032)\end{array}$ & $\begin{array}{c}0.130^{* * *} \\
(0.032)\end{array}$ & $\begin{array}{l}0.050^{\star} \\
(0.026)\end{array}$ & $\begin{array}{l}0.053^{\star *} \\
(0.024)\end{array}$ & $\begin{array}{l}0.058^{* *} \\
(0.025)\end{array}$ \\
\hline MRT & $\begin{array}{c}-0.001^{* * *} \\
(0.001)\end{array}$ & $\begin{array}{c}-0.001^{* * *} \\
(0.001)\end{array}$ & $\begin{array}{c}-0.001^{* * *} \\
(0.001)\end{array}$ & $\begin{array}{c}-0.001^{\star * *} \\
(0.001)\end{array}$ & $\begin{array}{c}-0.001^{* * *} \\
(0.001)\end{array}$ & $\begin{array}{c}-0.001^{* * *} \\
(0.001)\end{array}$ \\
\hline HISC & $\begin{array}{c}0.001 \\
(0.001)\end{array}$ & $\begin{array}{c}0.001 \\
(0.001)\end{array}$ & $\begin{array}{c}0.001 \\
(0.001)\end{array}$ & $\begin{array}{c}0.001 \\
(0.001)\end{array}$ & $\begin{array}{l}-0.001 \\
(0.001)\end{array}$ & $\begin{array}{l}-0.001 \\
(0.001)\end{array}$ \\
\hline JUNI & $\begin{array}{c}0.001 \\
(0.001) \\
\end{array}$ & $\begin{array}{l}-0.001 \\
(0.001)\end{array}$ & $\begin{array}{l}-0.001 \\
(0.001)\end{array}$ & $\begin{array}{c}0.001 \\
(0.001)\end{array}$ & $\begin{array}{l}-0.001 \\
(0.001)\end{array}$ & $\begin{array}{c}0.001 \\
(0.001)\end{array}$ \\
\hline PRIM & $\begin{array}{l}-0.001 \\
(0.001)\end{array}$ & $\begin{array}{c}\text { v0.001 } \\
(0.001)\end{array}$ & $\begin{array}{c}-0.001 \\
(0.001)\end{array}$ & $\begin{array}{c}-0.001^{* * *} \\
(0.001)\end{array}$ & $\begin{array}{c}-0.001^{* * *} \\
(0.001)\end{array}$ & $\begin{array}{c}-0.001^{* * *} \\
(0.001)\end{array}$ \\
\hline Spatial Lag $(\rho)$ & - & $\begin{array}{l}0.205^{\star * *} \\
(0.0130)\end{array}$ & - & - & $\begin{array}{c}0.298^{* * *} \\
(0.011)\end{array}$ & - \\
\hline $\operatorname{Lambda}(\lambda)$ & - & - & $\begin{array}{c}0.406^{* * *} \\
(0.022)\end{array}$ & - & - & $\begin{array}{c}0.472^{\star * *} \\
(0.016)\end{array}$ \\
\hline Breusch-Pagan & $1483.72^{\star * *}$ & $1436.74^{\star \star \star}$ & $1523.74^{\star * *}$ & $8491.93^{\star * *}$ & $7766.88^{\star * *}$ & $8929.17^{\star \star \star}$ \\
\hline Log Likelihood & -947.30 & -826.45 & -794.17 & -1140.42 & -803.25 & -729.85 \\
\hline SC & 2125.23 & 1892.06 & 1818.97 & 2522.28 & 1856.87 & 1701.13 \\
\hline AIC & 1948.61 & 1708.89 & 1642.35 & 2334.85 & 1662.49 & 1513.69 \\
\hline$R^{2}$ & 0.797 & 0.807 & 0.813 & 0.719 & 0.746 & 0.757 \\
\hline
\end{tabular}

Note: The estimated coefficient value are non-standardized. ${ }^{* * *}, * *$, and ${ }^{*}$ indicate that the coefficient reaches the $1 \%, 5 \%$, and $10 \%$ level of significance, respectively; significantly different from 0 . 
was 0.069 , reaching the $1 \%$ level of significance, which indicated that the housing prices in multistoried buildings and mansions were $6.9 \%$ higher than those in apartment houses. With regard to neighborhood characteristics, the coefficient of the distance to the nearest MRT station was -0.001 , indicating a $1 \%$ level of significance. The three coefficients of the distance to the nearest school did not attain the level of significance.

With regard to DD properties, the estimated coefficients of the construction license acquisition time for the three models were $0.427,0.427$, and 0.430 , reaching the $1 \%$ level of significance, which indicated that housing prices were $42.7 \%, 42.7 \%$, and $43.0 \%$ higher after the acquisition of a construction license by luxury housing than before. The estimated coefficients of location in the neighboring area were $0.021,0.012$, and 0.003 , and did not reach the $1 \%$ level of significance, indicating that there was no significant difference between housing prices in areas neighboring and not neighboring with luxury housing. The estimated coefficients of the interaction variable of construction license acquisition time and location in the neighboring area were $0.146,0.132$, and 0.130 , reaching the $1 \%$ level of significance. The DD estimated coefficients were $14.6 \%, 13.2 \%$, and $13.0 \%$. This indicated that the average difference in housing prices in areas neighboring and not neighboring luxury housing was $14.6 \%$, $13.2 \%$, and $13.0 \%$ during construction of luxury housing.

In the spatial error model, the spatial error coefficient $(\lambda)$ was 0.406 , reaching the $1 \%$ level of significance, which indicated that interference factors in error terms caused spatial autocorrelation. In the spatial lag model, the spatial lag coefficient $(\rho)$ was 0.205 , reaching the $1 \%$ level of significance, which indicated that housing prices were affected by neighboring housing prices.

\section{(2) After construction}

The results of three models regarding the period after the completion of luxury housing construction are discussed further. The Breusch-Pagan test was used to determine heteroscedasticity of residuals. Its values in three models were $8491.93,7766.88$, and 8929.17 , reaching the $1 \%$ level of significance. The value in the spatial error model was the highest, indicating heteroscedasticity of its residuals. $R^{2}$ was equal to $0.719,0.746$, and 0.757 ; the spatial error model showed the highest explanatory power. AIC was equal to $2334.85,1662.49$, and 1513.69 and SC was equal to $2522.28,1856.87$, and 1701.13 . The log likelihood values of the models were $-1140.42,-803.25$, and -729.85 , indicating that the bias could not be solved in the OLS regression model but could be solved in the spatial lag model and spatial error model. The results showed that the spatial error model was better than the traditional OLS regression model and spatial lag model. The evaluation results show that the spatial error model had the best goodness of fit. The results of the spatial error model are discussed further. With regard to property attributes, the results showed that the estimated coefficients and their significance levels were similar to those observed in the evaluation of data related to the period during construction. Thus, these results are not further described here. With regard to neighborhood characteristics, the coefficient of the distance to the nearest MRT station was -0.001 , indicating a $1 \%$ level of significance, and the coefficient of the distance to the nearest primary school was -0.001 , indicating a $1 \%$ level of significance.

With regard to DD properties, the estimated coefficients of the construction license acquisition time for the three models were $0.218,0.211$, and 0.228 , reaching the $1 \%$ level of significance, which indicated that housing prices were $21.8 \%, 21.1 \%$, and $22.8 \%$ higher after acquisition of a construction license by luxury housing than before. The estimated coefficients of location in the neighboring area were $0.050,0.014$, and 0.027 ; the coefficient in the OLS model reached the $5 \%$ level of significance and the coefficients in the spatial lag model and spatial error model have not reached the $10 \%$ level of significance. The estimated coefficients of the interaction variable of construction license acquisition time and location in the neighboring area were $0.050,0.053$, and 0.058 , reaching the level of significance. The DD estimated coefficients were $5.0 \%, 5.3 \%$, and $5.8 \%$.

In the spatial error model, the spatial error coefficient $(\lambda)$ was 0.472 , reaching the $1 \%$ level of significance, which indicated that interference factors in error terms caused spatial autocorrelation. In the spatial lag model, the spatial lag coefficient $(\rho)$ was 0.298 , reaching the $1 \%$ level of significance, which indicated that there was spatial dependence between neighboring areas and housing prices were affected by neighboring housing prices.

\section{Discussion}

The empirical results regarding basic property attributes indicated that the building transfer area had a significant positive effect on housing prices, which corresponded to the findings of Frew and Judd (2003), Martins-Filho and Bin (2005), and Abbott and Klaiber (2011). This indicated that prices of housing with larger area are higher. House age was found to have a significant and negative effect on housing prices, which corresponded to the results reported by Glasock et al. (2000), Osland (2010), and Bin and Landry (2013). With time, housing material and facilities become older, which reduces the housing price. The square of house age was found to significantly and positively affect housing prices, which corresponded to the results reported by Malpezzi et al. (1987), Geltner et al. (2010), and Bin and Landry (2013). The house age variable can have non-linear changes and, thus, the square of house age was added that was found to have a significant positive effect on housing prices. The number of rooms was found to significantly and positively affect housing prices, which corresponded to the results reported by McMillen and Redfearn (2010) and Paredes and Iturra (2013). A larger number of rooms was found to result in higher housing prices. The numbers of living rooms and bathrooms were found to significantly and positively affect housing prices, 
which corresponded to the results reported by Huang et al. (2010), Anselin and Lozano-Gracia (2008), McMillen and Redfearn (2010), and Baltagi and Bresson (2011). The numbers of living rooms and bathrooms were found to be a basic requirement of housing, making it more convenient. The residence floor coefficient was found to have a significant positive effect on housing prices, which corresponded to the results reported by Hong and Lin (1999) and Lin (2004). Properties located on the first floor are usually used for commerce and their price is relatively high, thus, increasing housing prices. The housing type significantly and positively affected housing prices, indicating that housing prices in multistoried buildings and mansions were higher than those in apartment houses. These results corresponded to findings of Chang et al. (2008) and Lin and Ma (2012), indicating that mansion costs are normally higher than those of apartment houses.

With regard to the DD properties, the interaction variable of construction license acquisition time and location in the neighboring area had a significant positive effect on housing prices and its estimated coefficient was equal 0.130 . This indicated that after the acquisition of a construction license by luxury housing, housing prices are significantly and positively affected within the influence range of luxury housing. The results showed that in this case, housing prices in neighboring areas of luxury housing increased by $13.0 \%$.

According to the results regarding the period after the completion of luxury housing construction, the interaction variable of usage license acquisition time and location in the neighboring area significantly and positively affected housing prices and its estimated coefficient was 0.058 . This indicated that after the acquisition of a usage license by luxury housing, housing prices are significantly and positively affected within the influence range of luxury housing. After the completion of construction, the housing prices in neighboring areas of luxury housing increased by $5.8 \%$. Thus, the external effects of completed luxury housing significantly and positively affected housing prices in the surrounding areas. Boyle and Kiel (2001) found that external environmental effects (such factors include air quality, water quality, and bad-land use in nearby areas) can affect housing prices. François et al. (2002) found that in Quebec City, Canada, beautiful streetscape could increase housing prices by $4.4 \%$. In addition to the external effects of housing, Hsu (2005) suggested that individual housing needs can also increase the BIRG phenomenon due to surrounding community characteristics; this involves location-, brand-, and quality-related cognition dimensions, all of which produce the neighborhood effect of luxury housing. The results corresponded to those reported by Ooi and Le (2013), François et al. (2002), Tang and Yao (2012), and Lee et al. (2018), that is, new constructions in neighboring areas are attractive and produce a positive effect. For example, the Olympics increased housing prices in Beijing that were particularly high in the periods close to the opening of the Olympics. The unique appearance and street design of luxury hous- ing make the surrounding streets and environment more beautiful, improving the quality of the neighborhood. The DD coefficients were $15.0 \%$ and $5.8 \%$, indicating that housing prices in the neighboring areas changed greatly, being affected by the psychological reaction to newly constructed luxury housing.

With regard to spatial econometric analysis, with the luxury housing construction set as the event, the spatial error coefficient $(\lambda)$ was 0.406 , reaching the $1 \%$ level of significance. The spatial lag coefficient $(\rho)$ was 0.205 , reaching the $1 \%$ level of significance. With the completion of luxury housing construction set as the event, the spatial error coefficient $(\lambda)$ was 0.472 , reaching the $1 \%$ level of significance. The spatial lag coefficient $(\rho)$ was 0.298 , reaching the $1 \%$ level of significance. Similar to studies by Lee et al. (2014), Chalermpong and Wattana (2010), and Basu and Thibodeau (1998), this study examined the presence of autocorrelation in housing prices and model error terms. The results showed spatial autocorrelation was present between housing market prices. This indicated that housing prices could be affected by neighboring housing prices. These results were as predicted. Baltagi et al. (2015) maintained that spatial phenomena are not independent and there is cluster or spillover spatial autocorrelation between neighboring spatial units. The significant and positive effect of the spatial lag coefficient indicated that housing prices can increase under the effect of neighboring housing prices.

This study integrated the estimated coefficients into the DD estimation chart developed by Hill et al. (2012), which indicated changes in housing prices in areas neighboring and not neighboring luxury housing during (indicated by a construction license) and after (indicated by a usage license) the construction of luxury housing (Figures 4 and 5).

Figure 4 shows the differences in housing prices before and after the luxury housing construction began. The results showed that before construction began, the coefficient was 5.270 in the areas within 500 meters from luxury housing (experimental group) and 5.267 in the areas outside this range (control group). The coefficient $\delta$

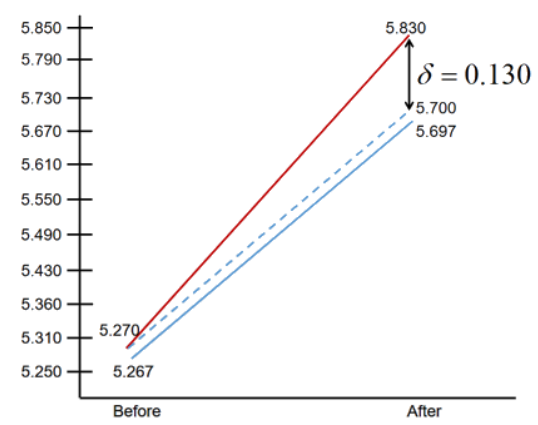

Blue line: control group, Red line: experimental group, Dashed line: experimental group's original tendency

Figure 4. Difference-in-differences estimation results: Beginning of luxury housing construction as the differentiation point 


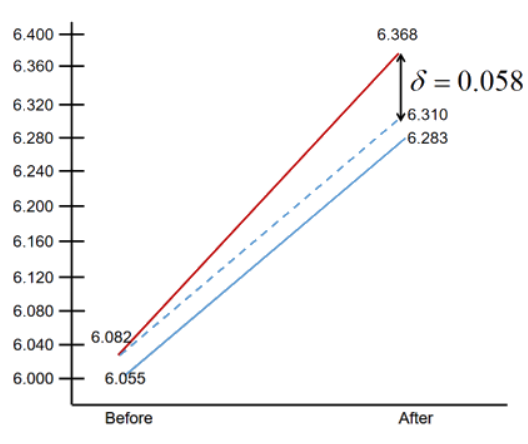

Blue line: control group, Red line: experimental group, Dashed line: experimental group's original tendency

Figure 5. Difference-in-differences estimation results: Completion of luxury housing construction as the differentiation point

after construction began was 5.830 in the areas within 500 meters from luxury housing (experimental group) and 5.697 in the areas outside this range (control group). After deducting the experimental group's original tendency of 0.003 , the difference in prices before and after construction of luxury housing began was 0.130 .

Figure 5 shows the differences in housing prices before and after the construction of luxury housing was completed. The results showed that before construction was completed, the coefficient was 6.082 in the areas within 500 meters from luxury housing (experimental group) and 6.055 in the areas outside this range (control group). The coefficient $\delta$ after construction was completed was 6.368 in the areas within 500 meters from luxury housing (experimental group) and 6.283 in the areas outside this range (control group). After deducting the experimental group's original tendency of 0.027 , the difference in prices before and after construction of luxury housing was completed was 0.058 .

This study used the DD method to estimate prices. The estimated coefficient were brought into $100\left(e^{\delta}-1\right) \%$ (Hill et al., 2012). The obtained values were multiplied by the mean value of housing prices in the sample to calculate the actual changes in housing prices. The difference in housing prices between the control group and experimental group after the acquisition of a construction license was NT $\$ 1,999,000$. After the acquisition of a usage license by luxury housing, the difference in housing prices between the control group and experimental group was NT\$1,130,300.

\section{Conclusion and suggestions}

Few studies have studied the effects of luxury housing events on housing prices nearby. Most have investigated the effects of large-scale public infrastructure development projects or large-scale housing development projects on housing prices nearby. Recently, Lee et al. (2018) investigated the effects of the announcement and the completion of luxury housing on nearby housing prices by adopting the DD approach for estimation.
This study integrated the DD method and spatial econometric analysis to examine the effect of differences before and after the event and in spatial location on housing prices. The OLS model does not consider spatial autocorrelation of neighboring housing prices. Therefore, the spatial lag model and spatial error model were used in order to improve bias that can be produced in the traditional OLS regression model and provide more accurate estimation results. The results of the spatial lag model of the effects during and after the construction of luxury housing indicated spatial correlation of neighboring housing prices. This corresponded to the conclusion made by Chalermpong and Wattana (2010).

This study investigated the effect of luxury housing on housing prices in neighboring areas during and after its construction. Apart from the main building, luxury housing focuses on street design and planning, which improves the quality of the neighborhood attributes and makes the area more beautiful; the quality of the neighborhood attributes improves due to increased amenity benefit. Higher prices of luxury housing cause spatial spillovers into and increase housing prices in neighboring areas. The results in this study showed that after the construction of luxury housing began, housing prices per ping in the neighboring areas increased by $15.3 \%$, indicating that luxury housing had a positive effect on housing prices within its influence range. After the construction of luxury housing was completed, housing prices per ping in the neighboring areas increased by $8.3 \%$, indicating the positive spillover effects of luxury housing both during and after its construction. Kavetsos (2012) and Ooi and Le (2013) found that new constructions positively affect a neighboring area, making it more attractive, improving the quality of neighborhood attributes, and increasing housing prices in the neighboring areas.

This study revealed that luxury housing has positive external effects or spillover effects on housing prices nearby. Next, as buyers have their own requirements for their houses, they would use the characteristics of surrounding groups to enhance the basking in reflected glory phenomenon (BIRG) of their self-image, such as location awareness, brand awareness, quality awareness, etc., which all reflect the neighborhood effects of luxury housing. In addition, the effects of the construction of luxury housing on housing prices nearby was significantly greater than that of their completion, which highlights the anticipatory response in the market.

The limitations of this study were related to data processing. In this study, only the recent linear distance between sample cases and luxury housing was estimated; however, it did not consider the actual geographic environment and urban street planning. These issues can be taken into account in future studies in order to estimate housing prices using more accurate methods that can better account for actual environments. With regard to the DD method, this study distinguished the experimental group and control group using a radius of 500 meters. Future studies can set different ranges and further analyze the effect of different distances on housing prices. 


\section{References}

Abbott, J. K., \& Klaiber, H. A. (2011). An embarrassment of riches: confronting omitted variable bias and multi-scale capitalization in hedonic price models. Review of Economics and Statistics, 93(4), 1331-1342. https://doi.org/10.1162/REST_a_00134

Anglin, P. M., \& Gencay, R. (1996). Semiparametric estimation of a hedonic price function. Journal of Applied Econometrics, 11(6), 633-648. https://doi.org/10.1002/(SICI)10991255(199611)11:6<633::AID-JAE414>3.0.CO;2-T

Anselin, L., \& Lozano-Gracia, N. (2008). Errors in variables and spatial effects in hedonic house price models of ambient air quality. Empirical Economics, 34(1), 5-34.

https://doi.org/10.1007/s00181-007-0152-3

Baltagi, B. H., \& Bresson, G. (2011). Maximum likelihood estimation and Lagrange multiplier tests for panel seemingly unrelated regressions with spatial lag and spatial errors: an application to hedonic housing prices in Paris. Journal of Urban Economics, 69(1), 24-42.

https://doi.org/10.1016/j.jue.2010.08.007

Baltagi, B. H., Bresson, G., \& Etienne, J. M. (2015). Hedonic housing prices in Paris: an unbalanced spatial lag pseudo panel model with nested random effects. Journal of Applied Econometrics, 30(3), 509-528. https://doi.org/10.1002/jae.2377

Basu, S., \& Thibodeau, T. G. (1998). Analysis of spatial autocorrelation in house price. Journal of Real Estate Finance and Economics, 17(1), 61-85. https://doi.org/10.1023/A:1007703229507

Bin, O., \& Landry, C. E. (2013). Changes in implicit flood risk premiums: empirical evidence from the housing market. Journal of Environmental Economics and Management, 65(3), 361-376. https://doi.org/10.1016/j.jeem.2012.12.002

Boen, F., Vanbeselaere, N., \& Feys, J. (2002). Behavioral consequences of fluctuating group success: an internet study of soccer-team fans. Journal of Social Psychology, 142(6), 769-781. https://doi.org/10.1080/00224540209603935

Bourassa, S., Cantoni, E., \& Hoesli, M. (2010). Predicting house prices with spatial dependence: a comparison of alternative methods. Journal of Real Estate Research, 32(2), 139-159.

Bourassa, S., Hoesli, M., \& Sun, J. (2004). What's in a view. Environment and Planning, 36(8), 1427-1450.

https://doi.org/10.1068/a36103

Bourassa, S., Hoesli, M., \& Sun, J. (2005). The price of aesthetic externalities. Journal of Real Estate Literature, 13(2), 165-188.

Boyle, M. A., \& Kiel, K. A. (2001). A survey of house price hedonic studies of the impact of environmental externalities. Journal of Real Estate Literature, 9(2), 117-144.

Can, A. (1990). The measurement of neighborhood dynamics in urban house prices. Economic Geography, 66(3), 254-272. https://doi.org/10.2307/143400

Can, A., \& Megbolugbe, I. (1997). Spatial dependence and house price index construction. Journal of Real Estate Finance and Economics, 14(1-2), 203-222.

https://doi.org/10.1023/A:1007744706720

Case, B., Clapp, J., Dubin, R., \& Rodriguez, M. (2004). Modeling spatial and temporal housing price patterns: a comparison of four models. Journal of Real Estate Finance and Economics, 29(2), 167-191.

https://doi.org/10.1023/B:REAL.0000035309.60607.53

Chalermpong, S., \& Wattana, K. (2010). Rent capitalization of access to rail transit stations: spatial hedonic models of office rent in Bangkok. Journal of the Eastern Asia Society for Transportation Studies, 29(8), 926-940.

https://doi.org/10.11175/eastpro.2009.0.186.0
Chang, C. O., Yang, C. H., \& Hung, Y. R. (2008). Developing, assessment and integration of the exist and presale housing price indexes-the case of Taipei City. Journal of Housing Studies, 17(2), 13-34.

Chen, C. J. (2008). Using geographically weighted regression model on the neighborhood effects of urban park [Unpublished master thesis]. Chinese Culture University, Taipei City, Taiwan.

Chen, F. C. (2011). Research on positioning design of luxury housing - a case study in Taipei Dazhi [Unpublished master thesis]. National Taiwan University of Science and Technology, Taipei City, Taiwan.

Chou, E. Y. (2012). The effects of inside-family vertical relationships on BIRG and CORF [Unpublished master thesis]. National Taipei University of Education, Taipei City, Taiwan.

Cordera, R., Chiarazzo, E., Ottomanelli, M., dell'Olio, L., \& Ibeas, A. (2019). The impact of undesirable externalities on residential property values: spatial regressive models and an empirical study, Transport Policy, 80, 177-187. https://doi.org/10.1016/j.tranpol.2018.04.010

Dempsey, J. A., \& Plantinga, A. J. (2013). How well do urban growth boundaries contain development? Results for Oregon using a difference-in-difference estimator. Regional Science and Urban Economics, 43(6), 996-1007.

https://doi.org/10.1016/j.regsciurbeco.2013.10.002

Dubé, J., Legros, D., Thériault, M., \& Des Rosiers, F. (2014). A spatial difference-in-differences estimator to evaluate the effect of change in public mass transit systems on house prices. Transportation Research Part B: Methodological, 64, 24-40. https://doi.org/10.1016/j.trb.2014.02.007

Dubé, J., Thériault, M., \& Des Rosiers, F. (2013). Commuter rail accessibility and house values: the case of the Montreal South Shore, Canada, 1992-2009. Transportation Research Part A: Policy and Practice, 54, 49-66. https://doi.org/10.1016/j.tra.2013.07.015

Dubin, R. A. (1998). Predicting house prices using multiple listings data. Journal of Real Estate Finance and Economics, 17(1), 35-48. https://doi.org/10.1023/A:1007751112669

Dubin, R., Pace, R. K., \& Thibodeau, T. G. (1999). Spatial autoregression techniques for real estate data. Journal of Real Estate Literature, 17(1), 79-95. https://doi.org/10.1023/A:1008690521599

Ellen, I. G., Schill, M. H., Susin, S., \& Schwartz, A. E. (2001). Building homes reviving neighborhoods: spillover from subsidized construction of owner-occupied housing in New York City. Journal of Housing Research, 12(2), 185-216.

François, D. R., Marius, T., Yan, K., \& Paul, V. (2002). Landscaping and house values: an empirical investigation. Journal of Real Estate Research, 23(1/2), 139-162.

Frew, J., \& Judd, G. D. (2003). Estimating the value of apartment buildings. Journal of Real Estate Research, 25(1), 77-86.

Geltner, D. M., Miller, N. G., Clayton, J., \& Eichholtz, P. (2010). Commercial real estate analysis and investments. South-Western Pub.

Gibbons, S., Machin, S., \& Sliva, O. (2013). Valuing school quality using boundary discontinuities. Journal of Urban Economics, 75, 15-28. https://doi.org/10.1016/j.jue.2012.11.001

Gibbons, S., Overman, H. G., \& Patacchini, E. (2015). Spatial methods. In G. Duranton, J. V. Henderson, \& W. C. Strange (Eds.), Handbook of regional and urban economics (Vol. 5, Ch. 3, pp. 115-168). https://doi.org/10.1016/B978-0-444-59517-1.00003-9

Glasock, J., Chiuling, L., \& Raymond, W. S. (2000). Further evidence on the integration of REIT, bond, and stock returns. Journal of Real Estate Finance and Economics, 20(2), 177-194. https://doi.org/10.1023/A:1007877321475 
Heil, O., \& Helsen, K. (2001). Toward an understanding of price wars: their nature and how they erupt. International Journal of Research in Marketing, 18(1-2), 83-98. https://doi.org/10.1016/S0167-8116(01)00033-7

Hill, R. C., Griffiths, W. E., \& Lim, G. C. (2012). Principles of econometrics (4nd ed.). John Wiley and Sons, Inc.

Ho, Y. F. (2011). Preliminary study on an appraisal model for luxury house via the structural equation model [Unpublished master thesis]. Chang Jung Christian University, Tainan City, Taiwan.

Hong, D. Y., \& Lin, C. C. (1999). A study on the impact of subway system and road width on the housing prices of Taipei. Journal of Housing Studies, 8, 47-67.

Hsu, H. J. (2005). The investment project evaluation model for the luxury mansions in Taichung City [Unpublished master thesis]. Chaoyang University of Technology, Taichung City, Taiwan.

Huang, B., Wu, B., \& Barry, M. (2010). Geographically and temporally weighted regression for modeling spatio-temporal variation in house prices. International Journal of Geographical Information Science, 24(3), 383-401.

https://doi.org/10.1080/13658810802672469

Imbens, G. W. (2015). Matching methods in practice: three examples. The Journal of Human Resources, 50(2), 373-419. https://doi.org/10.3368/jhr.50.2.373

Karl, G. L., \& Gareth, T. (2005). Parcel size, location and commercial land values. Journal of Real Estate Research, 27(3), 343-354.

Kavetsos, G. (2012). The impact of the London Olympics announcement on property prices. Urban Studies, 49(7), 14531470. https://doi.org/10.1177/0042098011415436

Kuan, P. Y., \& Lee, D. Y. (2008). Effects of cram schooling on math performance: a counterfactual analysis. Taiwanese Journal of Sociology, 41, 97-148.

Lee, C. C., Liang, C. M., Tung, C. H., \& Lu, Y. J. (2018). The impact of luxury housing on neighborhood housing prices in Taipei City. Asian Economic and Financial Review, 8(10), 1211-1225. https://doi.org/10.18488/journal.aefr.2018.810.1211.1225

Lee, C. C., Chang, W. L., \& Wu, Y. L. (2014). The impact of the crime rate and star schools on house prices: an analysis of spatial dependence. International Journal of Economics and Finance, 6(1), 99-113.

https://doi.org/10.1108/IJHMA-10-2015-0065

Liang, J. H. (2009). The spillover effect of refurbishment on housing price (Executive Yuan Project Reports No. NSC 98-2410H-034-025). National Science Council.

Lin, C. C., \& Ma, Y. C. (2012). An application of Bayesian inference in the real estate market-a case study of Taipei collective housing. Journal of Housing Studies, 21(1), 1-18.

Lin, J. H., \& Jou, S. C. (2005). High-income housing and their building blocks in Taipei: a case study of luxurious condominiums in Xinyi center. Journal of Geographical Science, 40, 17-43.

Lin, R. H. (2004). Taipei Xinyi Plan mansions. Architect, 8, 76-83.

Lin, S. J. (2004). The marginal willingness-to-pay of star public elementary and junior high school districts in Taipei City. Journal of Housing Studies, 13(1), 15-34.

Lin, T. Y. (2012). The relation between a monetary policy and housing prices (Research Proposal Report of the National Science Council). Executive Yuan.

Malpezzi, S., Ozanne, L., \& Thibodeau, T. G. (1987). Microeconomic estimates of housing depreciation. Land Economics, 63(4), 372-385. https://doi.org/10.2307/3146294
Martins-Filho, C., \& Bin, O. (2005). Estimation of hedonic price functions via additive nonparametric regression. Empirical and Economics, 30(1), 99-114. https://doi.org/10.1007/s00181-004-0224-6

McLean, A., Horváth, Á., \& Kiss, H. J. (2013). How does an increase in energy efficiency affect housing prices? A case study of a renovation. In 20th Annual Conference of the European Real Estate Society (pp. 39-55), Vienna.

McMillen, D. P., \& Redfearn, C. L. (2010). Estimation and hypothesis testing for nonparametric hedonic house price functions. Journal of Regional Science, 50(3), 172-733.

https://doi.org/10.1111/j.1467-9787.2010.00664.x

Morgan, S. L., \& Harding, D. J. (2006). Matching estimators of causal effects: prospects and pitfalls in theory and practice. Sociological Methods and Research, 35(1), 3-60.

https://doi.org/10.1177/0049124106289164

Ooi, J. T. L., \& Le, T. T. T. (2013). The spillover effects of infill developments on local housing price. Regional Science and Urban Economics, 43(6), 850-861.

https://doi.org/10.1016/j.regsciurbeco.2013.08.002

Osland, L. (2010). An application of spatial econometrics in relation to hedonic house price modeling. Journal of Real Estate Research, 32(3), 289-320.

Pace, R. K., \& Gilley, O. (1997). Using the spatial configuration of the data to improve estimation. Journal of Real Estate Finance and Economics, 14(3), 333-340.

https://doi.org/10.1023/A:1007762613901

Paredes, A. D., \& Iturra, R. V. (2013). Substitution bias and the construction of a spatial cost of living index. Papers in Regional Science, 92(1), 103-177.

https://doi.org/10.1111/pirs.2013.92.issue-1

Rosenbaum, P. R., \& Rubin, D. B. (1985). Constructing a control group using multivariate matched sampling methods that incorporate the propensity score. The American Statistician, 39(1), 33-38. https://doi.org/10.2307/2683903

Rubin, D. B. (1979). Using multivariate matched sampling and regression adjustment to control bias in observational studies. Journal of the American Statistical Association, 74(366a), 318-328. https://doi.org/10.1080/01621459.1979.10482513

So, H. M., Tse, R. Y. C., \& Ganesan, S. (1997). Estimating the influence of transport on house prices: evidence from Hong Kong. Journal of Property Investment and Finance, 15(1), 4047. https://doi.org/10.1108/14635789710163793

Song, Y., \& Knaap, G. J. (2003). New urbanism and housing values: a disaggregate assessment. Journal of Urban Economics, 54(2), 218-238.

https://doi.org/10.1016/S0094-1190(03)00059-7

Stuart, E. A., \& Rubin, D. B. (2008). Best practices in quasi-experimental designs. In J. W. Osborne (Ed.), Best practices in quantitative methods (pp. 155-176).

https://doi.org/10.4135/9781412995627.d14

Tang, X., \& Yao, Y. L. (2012). The impact of staging Olympic Games on real estate price in Beijing. Research in World Economy, 3(1), 45-53. https://doi.org/10.5430/rwe.v3n1p45

Tseng, Y. C. (2014). The capitalization of neighborhood effect the luxury house [Unpublished master thesis]. National Pingtung Institute of Commerce, Pingtung City, Taiwan.

Tsoodle, L. J., Golden, B. B., \& Featherstone, A. M. (2006). Factors influencing Kansas agricultural farm land values. Land Economics, 82(1), 124-139. https://doi.org/10.3368/le.82.1.124

Walls, M., Gerarden, T., Palmer, K., \& Bak, X. F. (2017). Is energy efficiency capitalized into home prices? Evidence from three US cities. Journal of Environmental Economics and Management, 82, 104-124. https://doi.org/10.1016/j.jeem.2016.11.006 
Wang, P. L. (2008). Study on the application of STP theory by construction companies - using luxury house as example [Unpublished master thesis]. Yuan Ze University, Taoyuan City, Taiwan.

$\mathrm{Wu}, \mathrm{F}$. (2010). Gated and packaged suburbia: packaging and branding Chinese suburban residential development. Cities, 27(5), 385-396. https://doi.org/10.1016/j.cities.2010.06.003

Wu, Y. Y. (2008). A study of purchasing behavior characteristics on residential luxury mansion market [Unpublished master thesis]. Tamkang University, New Taipei City.
Zang, J. Y. (2001). Taiwan's Third-generation mansion. Business Times, 33, 60-67.

Zietz, J., Zietz, E. N., \& Sirmans, G. S. (2008). Determinants of house prices: a quantile regression approach. Journal of Real Estate Finance and Economics, 37(4), 317-333. https://doi.org/10.1007/s11146-007-9053-7 